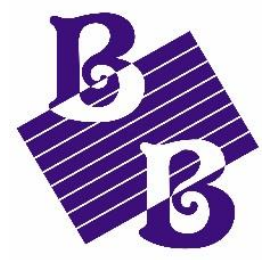

BioBacta
Journal of Bioscience and Applied Research www.jbaar.org

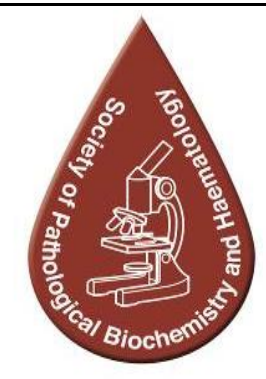

\title{
Effect of sewage water discharge on the Red Sea and shore
}

\section{Water and soil chemical characteristics}

\author{
Al-Zahrani Saeed, AL-Hasawi Zaki \\ Department of Biological Sciences, Faculty of Science, King Abdul Aziz University, Jeddah, Saudi Arabia \\ Received: March 1, 2018. Accepted: June 1, 2018. Published: June 10, 2018
}

DOI: 10.21608/JBAAR.2018.130082

\begin{abstract}
Jeddah City Saudi Arabia sewage water (untreated and treated) is discharged into the Red Sea water south of the city. The discharged water may contain harmful toxic elements that may affect the living organisms in the seawater, and also the coastal habitat particularly naturally growing plant species. A study was undertaken to assess and evaluate the concentrations of the macro-and microelements, the heavy and toxic metals, saults, and to determine acidity and conductivity of the Red Sea water and soil a, and the shore water and soil and compare them with results collected from an unpolluted area away from this affected area. The results indicated a highly significant accumulation of saults, macro, and micro-elements, and heavy and toxic metals in the sea and coastal water and soil compared to the unpolluted site. Out of all $\mathrm{Ca}, \mathrm{Na}$ and $\mathrm{Cl}$ in the sea and shore water expressed no significant differences between the polluted and unpolluted sites. For the sea and shore water, the highest concentrations were for $\mathrm{Mg}, \mathrm{K}$, and $\mathrm{P}$, while for their soil the highest concentrations were for $\mathrm{Ca}, \mathrm{Mg}, \mathrm{K}, \mathrm{P}, \mathrm{Na}$, and $\mathrm{Cl}$. AS for the heavy metals $\mathrm{Cu}, \mathrm{Mn}, \mathrm{Cr}, \mathrm{Al}, \mathrm{Zn}$, and $\mathrm{Co}$ dominated in the sea and shore water, while for the sea and shore soil the domination was for $\mathrm{Cu}, \mathrm{Mn}, \mathrm{B}, \mathrm{Cr}$, and $\mathrm{Al}$. Some of these elements, $\mathrm{Ca}, \mathrm{Mg}, \mathrm{Na}, \mathrm{K}, \mathrm{Cl}, \mathrm{Cu}, \mathrm{Cr}$, and $\mathrm{Ni}$ are concentrated at levels above that suggested and recommended by the Metreological Environmental Protection Agency (MEPA), Ministry of Water and Electricity (MWE) and Food and Agricultural Organization (FAO, 1985).
\end{abstract}

Key Words: Sewage water, Red seawater, Shore soil, macro-micro-elements

INTRODUCTION

Sewage water normally is discharged into seawater, and this practice creates a global problem. Sewage effluent discharge and human activities in the coastal areas and marine water led to the dumping of various kinds of pollutants such as heavy metals into the marine ecosystems (Censi et al. 2006; Pote 
et al. 2008). The high concentrations of metals and other elements in seawater cause several problems through their accumulation in the body of marine animals and organisms (Wen et al., 2007; Wcisio et al., 2008). In his comparison of the concentration of the metals $\mathrm{Al}, \mathrm{Fe}, \mathrm{Mn}, \mathrm{Cu}, \mathrm{Zn}, \mathrm{Cr}, \mathrm{Cd}$ and $\mathrm{Pb}$ in the Red Sea water southern Corniche area of Jeddah taken 1999 with those taken 2009 (Basaham et al. 2009) to see the effect of sewage effluent dumping in this area, and found that concentrations of these heavy metals were doubled during this period. The sewage water discharged into the Red Sea water is partially treated as polluted water, and the AlKhumra treatment plant in south Jeddah city which receives daily about $200,000-300,000 \mathrm{~m}^{3}$ sewage water partially treats this water (El-Sayed and Niaz,1999). The mean concentrations of the heavy metals $\mathrm{Zn}, \mathrm{Mn}, \mathrm{Cu}, \mathrm{Cd}$ in the Red Sea water in front of Jeddah City reached 8.00, 2.43, 1.7, and $1.09 \mathrm{i} 1 \mathrm{~g} / \mathrm{g}$ respectively (Saad and Fahmy,2009). The Red Sea coastal area water in the southern area of Jeddah City near the sewage effluent discharge was analyzed and the trace metals $\mathrm{Zn}, \mathrm{Cu}$, and Ni were found the metals with the highest concentrations (Radwan et al., 2009). In Jeddah City, there are 177 discharge points along Jeddah coast receiving treated and untreated sewage which is dumped directly into the Red Seawater and the most important of the effluent is that of Al-Khumra Sewage Treatment Plant (KSTP) which discharges its wastewater south of Jeddah with a daily amount of $(300,000 \mathrm{~m} 3)$ (El Sayed 2002b). On the other hand, the daily volume of sewage water discharged into the Red Sea waters in the vicinity of Jeddah city as declared by National Water Company reaches up to $375000 \mathrm{~m}^{3}$ (El-Riyadh Newspaper,7-5-2012). The average concentrations of $\mathrm{Fe}, \mathrm{Cu}$, and $\mathrm{Zn}$ in the sediment of the sewage effluent discharged in the Red Sea water were estimated by El-Yami (2010) as 8574,112 , and $1557 \mu \mathrm{g} / \mathrm{g}$. El-Nakhlawy et al., (2016) mentioned that wastewater irrigated areas produced the highest concentration of toxic metals in plant and soil samples compared to irrigated sites with normal water. The discharge of the industrial wastewater in seawater near the city of Zonguldak beaches was assessed by Coban et al. (2009) and found to have the following concentrations $\mathrm{Mn}$ $15.0 \pm 0.98, \mathrm{Cr} 12 \pm 8.6, \mathrm{Mg} 715 \pm 8.3, \mathrm{Cu}$ i $22 \pm 1.5, \mathrm{Ni}$ $142 \pm ı 0.6, \mathrm{~Pb} 39 \pm 9.0$ and $\mathrm{Zn} 834 \pm 4.1$. This study aims to estimate the concentration of chemicals, elements, salts, trace, and heavy metals in sewage water, Sea and shore water of Red Sea south of Jeddah City, Saudi Arabia as affected by sewage water discharge and compare it with unpolluted location $30 \mathrm{~km}$ away.

\section{Materials and Methods}

\section{Collection of water samples:}

Seawater samples were collected from twelve points along the coastal region from a depth of $30 \mathrm{~cm}$ and placed in sealed clean glass bottles with all the information's written, and taken to the laboratory

The water samples $(5 \mathrm{~L})$ were filtered through filter papers and put into clean bottles for analysis. Also, water samples were collected from the sewage water discharged into the seawater, finally treated, secondarily treated, and untreated.

\section{Collection of soil samples:}

Soil samples were collected from twelve points inside the Red Sea coastal water, and twelve points along the shore at depth of $(0-30 \mathrm{~cm})$ and placed in plastic bags and taken to the laboratory. The samples were dried at $60^{\circ} \mathrm{C}$ in an oven for 24 hours and passed through a thieve $2 \mathrm{~mm}$ aperture, and then mixed thoroughly. To prepare soil filtrate 50 gm were taken in a flask and $250 \mathrm{ml}$ of distilled water were added and the flasks closed and placed in a vibrator for 6 hours. The filtrate was then filtered through Whitman filter paper and placed in bottles and put in the fridge for analysis.

Analysis of the samples:

$\mathrm{pH}$ value:

$\mathrm{pH}$ value was analyzed using the $\mathrm{pH}$-meter Titrator Mettler DL55.

EC;

It was determined using the EC-meter model Mettler MC 226.

Determination of macro-elements and heavy metals:

Many instruments were used for the determination of macro-elements and heavy 
metals, like Atomic Absorption Spectrophotometer, Model Analyst 800, Perkin Elmer (USA). The instrument Inductively Coupled Plasma, Optical Emission Spectrometer, Model Optima 4100 DV Perkin. The following formula was used to calculate the concentration in $\mathrm{mg} / \mathrm{kg}$ of SPM $\mathrm{mg} / \mathrm{kg}$ (Dry weight $)=$ Concentration* Dilution $/$ Dry weigh .

TDS:

The amount of TDS in a water sample is measured by filtering the sample through a 2.0 $\mu \mathrm{m}$ pore size filter, evaporating the remaining filtrate, and then drying what is left to a constant weight at $180^{\circ} \mathrm{C}$.

\section{Statistical analysis}

The collected data were statistically analyzed using the analysis of variance (ANOVA) and mean comparisons (Least Significant Difference (LSD) test) according to El-Nakhlawy (2008), using SPSS (Statistical Package for the Social Sciences) version 13.0.

\section{RESULTS}

The concentration of the main elements in normal water and sewage water semi-treated and untreated:

Table (1) illustrates the mean concentrations of the main elements analyzed in the tap water and the semi-treated and untreated sewage water. Sewage water does not affect the $\mathrm{pH}$ of the water and it remained 6.5 as in the tap water. The total dissolved solids (TDS) increased in the untreated sewage water to a very high rate of $2450 \mathrm{mg} / \mathrm{L}$ and doubled to 94.2 times compared to tap water TDS concentrations. The total suspended solids (TSS) concentration also increased to a high level in sewage water reaching $362 \mathrm{mg} / \mathrm{L}$ or 67 times greater than tap water with only $5.4 \mathrm{mg} / \mathrm{L}$. The carbonates $\left(\mathrm{HCO}_{3}\right)$ are very high in sewage water with a concentration of $415 \mathrm{mg} / \mathrm{L}$ compared to tap water with only $5.9 \mathrm{mg} / \mathrm{L}$. The sulfates (SO4) are very high in the sewage $(1296 \mathrm{mg} / \mathrm{L})$ and semi-treated sewage $1108 \mathrm{mg} / \mathrm{L}$ ) water compared to tap water (246 $\mathrm{mg} / \mathrm{L})$. The phosphates are high in the untreated sewage water $(25.5 \mathrm{mg} / \mathrm{LO}$ and $0.1<$ in the tap water. Ammonium $\left(\mathrm{NH}_{4}\right)$, nitrates $\left(\mathrm{NO}_{3}\right)$, and nitrites $\left(\mathrm{NO}_{2}\right)$ are also low in the tap water compared to untreated sewage water. The macro-elements $\mathrm{Ca}, \mathrm{Mg}, \mathrm{K}, \mathrm{Fe}$ are high in the sewage water compared to tap water, while $\mathrm{Na}$ and $\mathrm{Cl}$ are very high in sewage water (576 and $768 \mathrm{mg} / \mathrm{L}$ ) compared to tap water with $0.1<\mathrm{mg} / \mathrm{L}$. 
Table (1): Concentration of the main elements $(\mathrm{mg} / \mathrm{L})$ in normal water and sewage water semi-treated and untreated:

\begin{tabular}{|c|c|c|c|}
\hline \multicolumn{2}{|c|}{} & \multicolumn{2}{c|}{ Sewage water } \\
\hline $\begin{array}{c}\text { Elemen } \\
\mathrm{p}\end{array}$ & $\begin{array}{c}\text { Tap } \\
\text { water }\end{array}$ & untreated & $\begin{array}{c}\text { Semi- } \\
\text { treated }\end{array}$ \\
\hline $\mathrm{pH}$ & 6.5 & 6.3 & 6.5 \\
\hline $\mathrm{TDS}$ & 25.8 & 2450 & 25.8 \\
\hline $\mathrm{TSS}$ & 5.4 & 362 & 5.6 \\
\hline $\mathrm{HCO}_{3}$ & 5.9 & 415 & 60.2 \\
\hline $\mathrm{SO}_{4}$ & 246 & 1296 & 1108 \\
\hline $\mathrm{PO}_{4}$ & $0.1<$ & 25,5 & $0.1<$ \\
\hline $\mathrm{NH}_{4}$ & 9.1 & 23.8 & 20.5 \\
\hline $\mathrm{NO}_{3}$ & 7.3 & 22.4 & 10.2 \\
\hline $\mathrm{NO}$ & 0.2 & 0.34 & 0.6 \\
\hline $\mathrm{Ca}$ & 5.2 & 86.8 & 6.6 \\
\hline $\mathrm{Mg}$ & 11.5 & 25.4 & 23.7 \\
\hline $\mathrm{K}$ & $0.1<$ & 21.4 & $0.1<$ \\
\hline $\mathrm{Fe}$ & $0.1<$ & 0,1 & $0.1<$ \\
\hline $\mathrm{Na}$ & $0.1<$ & 576 & $0.1<$ \\
\hline $\mathrm{Cl}$ & $0.1<$ & 768 & $0.1<$ \\
\hline
\end{tabular}

\section{The concentration of micro and heavy metals in normal water} and sewage water semi-treated and untreated:

Table (2) illustrates that 8 of the heavy metals zinc $(\mathrm{Zn})$, copper $(\mathrm{Cu})$, manganese $(\mathrm{Mn})$, boron (B), chromium (Cr), nickel $(\mathrm{Ni})$ arsenic $(\mathrm{As})$, and barium $(\mathrm{Ba})$ present in the untreated sewage water at concentrations significantly higher than their concentrations in the tap water, with B attaining very high concentration (1296 mg/L) in the untreated SW and $1108 \mathrm{mg} / \mathrm{L}$ in the semi-treated SW. The heavy metals molybdenum (Mo), mercury $(\mathrm{Hg})$, cadmium (Cd), silver (Ag), aluminum (Al), cobalt (Co), selenium (Se) concentrations in all types of water are negligible $(0.1<)$.

There is no significant difference in the concentration of $\mathrm{Pb}$ between tap and sewage water. 
Table (2): Concentration of micro and heavy metals $(\mathrm{mg} / \mathrm{L})$ in normal water and sewage water semi-treated and untreated:

\begin{tabular}{|c|c|c|c|}
\hline \multicolumn{2}{|c|}{} & \multicolumn{2}{c|}{ Sewage water } \\
\hline Element & $\begin{array}{c}\text { Tap } \\
\text { water }\end{array}$ & untreated & $\begin{array}{c}\text { Semi- } \\
\text { treated }\end{array}$ \\
\hline $\mathrm{Zn}$ & 3.3 & 25.8 & 25.8 \\
\hline $\mathrm{Cu}$ & 2.8 & 5.6 & 5.4 \\
\hline $\mathrm{Mn}$ & 0.9 & 60.2 & 5.9 \\
\hline $\mathrm{B}$ & 4.8 & 1296 & 1108 \\
\hline $\mathrm{Mo}$ & $0.1<$ & $0.1<$ & $0.1<$ \\
\hline $\mathrm{Cr}$ & 1.6 & 20.5 & 9.1 \\
\hline $\mathrm{Ni}$ & 4.1 & 10.2 & 7.3 \\
\hline $\mathrm{Pb}$ & 0.5 & 0.6 & 0.2 \\
\hline $\mathrm{As}$ & 0.13 & 6.6 & 5.2 \\
\hline $\mathrm{Ba}$ & 10 & 23.7 & 11.5 \\
\hline $\mathrm{Hg}$ & $0.1<$ & $0.1<$ & $0.1<$ \\
\hline $\mathrm{Cd}$ & $0.1<$ & $0.1<$ & $0.1<$ \\
\hline $\mathrm{Ag}$ & $0.1<$ & $0.1<$ & $0.1<$ \\
\hline $\mathrm{Al}$ & $0.1<$ & $0.1<$ & $0.1<$ \\
\hline $\mathrm{Co}$ & $0.1<$ & $0.1<$ & $0.1<$ \\
\hline $\mathrm{Se}$ & $0.1<$ & $0.1<$ & $0.1<$ \\
\hline
\end{tabular}

Mean values of $\mathrm{pH}$ in seawater and shore water, and sea soil and shore soil:

There are no significant differences between values of the $\mathrm{pH}$ in the samples of water of the polluted and unpolluted sites in the sea and the shore and coastal areas.

Table (3): $\mathrm{pH}$ values in the sea and shore water and soil (means + standard deviation):

\begin{tabular}{|r|r|r|r|r|}
\hline & Polluted site & $\begin{array}{r}\text { Unpolluted } \\
\text { site }\end{array}$ & Significance \\
\hline \multirow{2}{*}{ Sater } & Sea water & $7 ., 8 \pm 0,01$ & $7.7 \pm 0,001$ & 0.781 \\
\cline { 2 - 5 } & Shore water & $7.9 \pm 0,001$ & $7.8 \pm 0,001$ & 0.712 \\
\hline \multirow{2}{*}{ Soil } & Shore soil & $7.9 \pm 0,01$ & $7.4 \pm 0,21$ & 0.217 \\
\cline { 2 - 5 } & Coastal soil & $7.8 \pm 0,1$ & $7.6 \pm 0,04$ & 0.351 \\
\hline
\end{tabular}


Mean values of EC in the sea and shore water, and sea and shore soil:

Table (4) illustrates that the site polluted by sewage water exhibited high electric conductivity (EC) in both Seawater and soil and both shore water and soil compared to the unpolluted site, with the shore water giving the highest EC $(8.6 \mathrm{~mm} / \mathrm{cc})$.

Table (4): EC values in the sea and shore water and soil (millimole/cm) (means + standard deviation):

\begin{tabular}{|r|r|r|r|r|}
\hline & Type of sample & Polluted site & Unpolluted site & Significance \\
\hline \multirow{2}{*}{ Water } & Sea water & $5.7 \pm 0.19$ & $4.4 \pm 0.01$ & $0.031^{*}$ \\
\cline { 2 - 5 } & Shore water & $8.6 \pm 0,01$ & $5.1 \pm 0.001$ & $0.032^{*}$ \\
\hline \multirow{2}{*}{ Soil } & Shore soil & $7.3 \pm 1.3$ & $5.9 \pm 1.1$ & $0.029^{*}$ \\
\cline { 2 - 5 } & Coastal soil & $6.9 \pm 0.4$ & $5.4 \pm 0.01$ & $0.026^{*}$ \\
\hline
\end{tabular}

\section{The concentration of macroelements in Sea Water} and shore water In polluted and unpolluted sites :

Table (5) illustrates that the concentrations of the macro-elements $\mathrm{Mg}, \mathrm{K}$, and $\mathrm{P}$ are significantly high in the Sea Water and shore water is polluted site compared to the unpolluted site, but $\mathrm{Ca}, \mathrm{Na}$ and $\mathrm{Cl}$ show no significant variation in concentration in polluted and unpolluted sites. Sodium ( $\mathrm{Na}$ ) and $\mathrm{Cl}$ gave very high concentrations in the Sea and shore waters in polluted and unpolluted sites, and the high concentrations of $\mathrm{Cl}$ and $\mathrm{Na}$ in the soil may be related to a high concentration of soluble salts. The concentration of the six macro-elements in the shore water is higher than their concentration in the Seawater.

Table (5): Concentration ( $\mathrm{mg} / \mathrm{L}$ ) of macroelements in Sea Water and shore water in polluted and unpolluted sites :

\begin{tabular}{|c|c|r|r|r|}
\hline Element & Source & \multicolumn{1}{c|}{ Polluted } & \multicolumn{1}{c|}{ unpolluted } & \multicolumn{1}{c|}{ Significance } \\
\hline \multirow{2}{*}{$\mathrm{Ca}$} & Sea water & $446 \pm 96$ & $420 \pm 59$ & 0.219 \\
\cline { 2 - 5 } & $\begin{array}{c}\text { Shore } \\
\text { water }\end{array}$ & $531 \pm 107$ & $491 \pm 11$ & 0.070 \\
\hline \multirow{2}{*}{$\mathrm{Mg}$} & Sea water & $1495 \pm 50$ & $121 \pm 67$ & $0.010^{* *}$ \\
\cline { 2 - 5 } & $\begin{array}{c}\text { Shore } \\
\text { water }\end{array}$ & $1757 \pm 19$ & $14 \pm 147$ & $0.010^{* *}$ \\
\hline \multirow{2}{*}{$\mathrm{K}$} & Sea water & $44.9 \pm 3.9$ & $44 \pm 4.1$ & $0.001^{* *}$ \\
\cline { 2 - 5 } & $\begin{array}{c}\text { Shore } \\
\text { water }\end{array}$ & $60.1 \pm 9.9$ & $49 \pm 14$ & $0.004^{* *}$ \\
\hline $\mathrm{P}$ & Sea water & $18.7 \pm 0.6$ & $10.9 \pm 0.02$ & $0.051^{* *}$ \\
\cline { 2 - 5 } & $\begin{array}{c}\text { Shore } \\
\text { water }\end{array}$ & $28.2 \pm 1.2$ & $12.7 \pm 1.6$ & $0.032^{* *}$ \\
\hline $\mathrm{Na}$ & Sea water & $11561 \pm 251$ & $11397 \pm 28$ & 0.690 \\
\cline { 2 - 5 } & $\begin{array}{c}\text { Shore } \\
\text { water }\end{array}$ & $13373 \pm 184$ & $11350 \pm 218$ & 0.190 \\
\hline $\mathrm{Cl}$ & Sea water & $15722 \pm 122$ & $14312 \pm 89$ & 0.102 \\
\cline { 2 - 5 } & $\begin{array}{l}\text { Shore } \\
\text { water }\end{array}$ & $19702 \pm 209$ & $18588 \pm 193$ & 0.352 \\
\hline
\end{tabular}


The concentration of macroelements in Sea soil and shore soil in polluted and unpolluted sites :

Table (6) illustrates that the concentrations of the macro-elements $\mathrm{Ca}, \mathrm{Mg}, \mathrm{K}, \mathrm{P}, \mathrm{Na}$ are significantly high in the Sea soil and shore soil in polluted site compared to the unpolluted site, but $\mathrm{Cl}$ shows no significant variation in concentration in polluted and unpolluted sites. Chlorides $(\mathrm{Cl})$ gave very high concentration in the Sea and shore soils in polluted and unpolluted sites, then $\mathrm{Na}$ also gave high concentrations. Potassium (K) and $\mathrm{P}$ gave the lowest concentrations in both polluted and unpolluted sites in both Sea and shore soils compared to other elements. The high concentrations of $\mathrm{Cl}$ and $\mathrm{Na}$ in the soil may be related to a high concentration of soluble salts.

Table (6): Concentration ( $\mathrm{mg} / \mathrm{L}$ ) of macroelements in Sea soil and shore soil in polluted and unpolluted sites :

\begin{tabular}{|c|c|c|c|c|}
\hline Element & Source & Polluted & unpolluted & Significance \\
\hline \multirow{2}{*}{$\mathrm{Ca}$} & Sea soil & $728 \pm 38$ & $661 \pm 42$ & $0.042^{* *}$ \\
\cline { 2 - 5 } & Shore soil & $1333 \pm 32$ & $948 \pm 14$ & $0.036^{*}$ \\
\hline \multirow{2}{*}{$\mathrm{Mg}$} & Sea soil & $1131 \pm 35$ & $114 \pm 21$ & $0.001^{* *}$ \\
\cline { 2 - 5 } & Shore soil & $1011 \pm 28$ & $292 \pm 49$ & $0.005^{* *}$ \\
\hline \multirow{2}{*}{$\mathrm{K}$} & Sea soil & $382 \pm 3,2$ & $52 \pm 4,5$ & $0.002^{* *}$ \\
\cline { 2 - 5 } & Shore soil & $284 \pm 1,6$ & $61 \pm 2,7$ & $0.001^{* *}$ \\
\hline $\mathrm{P}$ & Sea soil & $34.5 \pm 0.3$ & $19.3 \pm 0.9$ & $0.049^{* *}$ \\
\cline { 2 - 5 } & Shore soil & $38.7 \pm 2,7$ & $18.1 \pm 0,8$ & $0.37^{*}$ \\
\hline \multirow{2}{*}{$\mathrm{Na}$} & Sea soil & $10208 \pm 108$ & $7773 \pm 288$ & $0.035^{*}$ \\
\cline { 2 - 5 } & Shore soil & $6117 \pm 14$ & $5370 \pm 22$ & $0.028^{*}$ \\
\hline \multirow{2}{*}{$\mathrm{Cl}$} & Sea soil & $22281 \pm 257$ & $19115 \pm 601$ & 0.022 \\
\cline { 2 - 5 } & Shore soil & $21001 \pm 174$ & $18444 \pm 236$ & 0.019 \\
\hline
\end{tabular}




\section{Concentration of trace and heavy metals in Sea Water and shore water in polluted and unpolluted sites :}

Table (7) illustrates that the concentrations of the heavy metals $\mathrm{Cu}, \mathrm{Mn}, \mathrm{Cr}, \mathrm{Ni}$, and $\mathrm{Al}$ are significantly high in the Seawater and shore water in polluted site compared to the unpolluted site, and the other four metals $\mathrm{Zn}$, $\mathrm{Mo}, \mathrm{Co}$, and Fe show no significant variation in concentration in polluted and unpolluted sites. Manganese (Mn) gave high concentration in the Sea and shore water in polluted and unpolluted sites compared to the other metals, and its concentration in water of polluted site in very high $(84 . \mathrm{Mg} / \mathrm{L})$ compared to its concentration in the unpolluted site $(0.14 \mathrm{mg} / \mathrm{L})$, while $\mathrm{Zn}$, Co, Mo, Fe gave very low concentrations in both polluted and unpolluted sites in both Sea and shore water compared to other elements. These results correlated with the results of Gupta et al. (2008) who analyzed the chemical constituents of effluent released from sponge iron industries and distribution of heavy metals in the soil near to effluent discharge channel and found that the concentration of total suspended solids (TSS), total hardness (TH), iron $\left(\mathrm{Fe}^{2+}\right)$, are greater in the nearby water than in water away from this site, and in the soil along the sides of the effluent channel also shows a higher concentration of heavy metals than the background soil.

Table (7): Concentration (mg/L) of heavy metals in Sea Water and shore water In polluted and unpolluted sites :

\begin{tabular}{|c|c|c|c|c|}
\hline Element & Water & Polluted & unpolluted & Significance \\
\hline \multirow[t]{2}{*}{$\mathrm{Zn}$} & Sea water & $0.12 \pm 0,001$ & 0.1 & \\
\hline & Shore water & 0.1 & 0.1 & \\
\hline \multirow[t]{2}{*}{$\mathrm{Cu}$} & Sea water & $0.12 \pm 0,001$ & $0.02 \pm 0,003$ & $0.001^{* *}$ \\
\hline & Shore water & $0.13 \pm 0,002$ & $0.03 \pm 0,001$ & $0.001 * *$ \\
\hline \multirow[t]{2}{*}{$\mathrm{Mn}$} & Sea water & $84 \pm 0,02$ & $0.14 \pm 0,001$ & $0.001^{* *}$ \\
\hline & Shore water & $6.27 \pm 1,3$ & $0.17 \pm 0,001$ & $0.001 * *$ \\
\hline \multirow[t]{2}{*}{ B } & Sea water & $5.34 \pm 0,34$ & $4.08 \pm 0,28$ & 0.152 \\
\hline & Shore water & $6.57 \pm 0,74$ & $5.19 \pm 0,28$ & 0.211 \\
\hline \multirow[t]{2}{*}{$\mathrm{Cr}$} & Sea water & $0.13 \pm 0,001$ & $0,0002 \pm 0,001$ & $0.006 * *$ \\
\hline & Shore water & $0.13 \pm 0,002$ & $0,002 \pm 0,001$ & $0.006 * *$ \\
\hline \multirow[t]{2}{*}{$\mathrm{Ni}$} & Sea water & $0.14 \pm 0,002$ & $0,001 \pm 0,001$ & $0.001 * *$ \\
\hline & Shore water & $0.11 \pm 0,001$ & $0,002 \pm 0,002$ & $0.001 * *$ \\
\hline \multirow[t]{2}{*}{ Mo } & Seawater & 0.1 & 0.1 & \\
\hline & Shore water & 0.1 & 0.1 & \\
\hline \multirow[t]{2}{*}{$\mathrm{Al}$} & Seawater & $1.9 \pm 0,001$ & & \\
\hline & Shore water & $2.1 \pm 0,01$ & 0.001 & $0.001 * *$ \\
\hline \multirow[t]{2}{*}{ Co } & Sea water & 0.01 & 0.001 & \\
\hline & Shore water & 0.002 & 0.1 & \\
\hline \multirow[t]{2}{*}{$\mathrm{Fe}$} & Sea water & $0.1<$ & 0.1 & \\
\hline & Shore water & & & \\
\hline
\end{tabular}


The concentration of micro and heavy metals in Sea soil and shore soil in polluted and unpolluted sites :

Table (8) shows that there are significant differences in heavy metal concentrations between Sea soil and shore soil except for $\mathrm{Zn}, \mathrm{Cr}$, and Fe, and concentrations are low except for $\mathrm{Mn}$ with (8.74 mg/L) and $(3.21 \mathrm{mg} / \mathrm{L})$ in Sea and shore soil and B $(6.91 \mathrm{mg} / \mathrm{L})$ in Shore soil.

Table (8): Concentration ( $\mathrm{mg} / \mathrm{L}$ ) of heavy metals in Sea soil and shore soil In polluted and unpolluted sites :

\begin{tabular}{|c|c|c|c|c|}
\hline Element & Water & Polluted & unpolluted & Significance \\
\hline \multirow[t]{2}{*}{$\mathrm{Zn}$} & Sea soil & $0.1<$ & $0.1<$ & \\
\hline & Shore soil & $0.1<$ & $0.1<$ & \\
\hline \multirow[t]{2}{*}{$\mathrm{Cu}$} & Sea soil & $0.07 \pm 0,00004$ & $0.02 \pm 0,003$ & $0.025^{*}$ \\
\hline & Shore soil & $0.9 \pm 0,001$ & $0.03 \pm 0,001$ & $0.015^{*}$ \\
\hline \multirow[t]{2}{*}{$\mathrm{Mn}$} & Sea soil & $8.74 \pm 0,92$ & $0.24 \pm 0,06$ & $0.001^{* *}$ \\
\hline & Shore soil & $3.21 \pm 1,7$ & $0.37 \pm 0,02$ & $0.001^{* *}$ \\
\hline \multirow[t]{2}{*}{ B } & Sea soil & $0.1 \pm 0,06$ & $2.49 \pm 0,03$ & $0.009 * *$ \\
\hline & Shore soil & $6.91 \pm 0,02$ & $2.48 \pm 0,03$ & $0.007 * *$ \\
\hline \multirow[t]{2}{*}{$\mathrm{Cr}$} & Sea soil & $0.1<$ & $0.1<$ & \\
\hline & Shore soil & $0.1<$ & $0.1<$ & \\
\hline \multirow[t]{2}{*}{$\mathrm{Ni}$} & Sea soil & $013 \pm 0,001$ & $0.001 \pm 0,0001$ & $0.006 * *$ \\
\hline & Shore soil & $0.12 \pm 0,001$ & $0.001 \pm 0,0001$ & $0.006 * *$ \\
\hline \multirow[t]{2}{*}{ Mo } & Sea soil & 0.01 & & \\
\hline & Shore soil & 0.01 & & \\
\hline \multirow[t]{2}{*}{$\mathrm{Al}$} & Sea soil & 0.02 & & \\
\hline & Shore soil & 0.08 & & \\
\hline \multirow[t]{2}{*}{ Co } & Sea soil & $1.3 \pm 0,002$ & $0.03 \pm 0,001$ & $0.007^{* *}$ \\
\hline & Shore soil & $0.24 \pm 0,003$ & 0,001 & $0.004 * *$ \\
\hline \multirow[t]{2}{*}{$\mathrm{Fe}$} & Sea soil & 0,003 & 0,001 & \\
\hline & Shore soil & 0,002 & 0,001 & \\
\hline
\end{tabular}

\section{DISCUSSION}

\section{$\mathrm{pH}$ value:}

$\mathrm{pH}$ is an indicator of the acidity or basicity of water but is seldom a problem by itself. The normal $\mathrm{pH}$ range for irrigation water is from 6.5 to $8.4 ; \mathrm{pH}$ values outside this range are a good warning that the water is abnormal in quality. The results indicated no significant differences in $\mathrm{pH}$ values in the sewage water and tap water and it ranged between (6.3-6.5), and also in Sea and shore water, and Sea and shore soil and ranged between (7.4-7.9). So pH reduced in sewage water compared to tap water and this agrees with the finding of 
Alghobara et al. (2014), but not with the findings of Ghafoor et al. (1995) who mentioned an increase of $\mathrm{pH}$ value in sewage water compared to normal water. On the other hand El-Khateeb et al.

(2012) found $\mathrm{pH}$ in sewage water to range between (8.01 to 8.40). It seems that $\mathrm{pH}$ value in sewage water varies according to elements and constituents dumped in the sewage water.

\section{Electrical conductivity (EC):}

Electrical conductivity (EC) is widely used to indicate the total ionized constituents of water. It is directly related to the sum of the cations (or anions), as determined chemically, and is closely correlated, in general, with the total salt concentration. Electrical conductivity is significantly high $(\leq 0.05)$ in Sea and shore water and Sea and shore soil in the polluted site compared to unpolluted soil and is highest in the polluted shore soil $(8.6 \mathrm{ds} / \mathrm{m})$. This finding agrees with that of Alghobara et al. (2014) who found an increase in EC of soil irrigated with sewage water, and an increase in EC is due to salt input.

\section{Macro-elements in sewage water and tap water:}

Sewage water is mainly comprised of water (99.9\%) together with suspended and dissolved organic and inorganic solids. The physicochemical characters studied are total dissolved solids (TDS), total suspended solids (TSS), calcium, magnesium, chloride, potassium, iron, sodium, chlorides. An increase in TDS concentrations in polluted waters often result from industrial effluent, changes to the water balance (by limiting inflow, by increased water use or increased precipitation), or by the salt-water intrusion. The total dissolved solids (TDS) in untreated sewage water is very high ( $2450 \mathrm{ds} / \mathrm{m})$ compared to tap water $(25 . / \mathrm{ds} / \mathrm{m})$, also the sulfate $\left(\mathrm{SO}_{4}\right)$ is very high in sewage water $(1296$ $\mathrm{ds} / \mathrm{m})$ compared to tap water $(246 \mathrm{ds} / \mathrm{m})$. This is positively correlated with the finding of Al-Salem (1987) were the total dissolved solids IN AMMAN, JORDAN ranged up to $1170 \mathrm{mg} / \mathrm{l}$, while in other places it is low, Krishnan et al. (2007) registered TDS in sewage water to be $200 \mathrm{mg} / \mathrm{L}$ in three different places of Sivakasi. This indicates that TDS concentration in sewage water varies with variations in organic and inorganic materials deposited in the water. The term TSS is often used to describe the concentration of solid-phase material suspended in a water-sediment mixture and usually expressed in milligrams per liter $(\mathrm{mg} / \mathrm{L})$. The total suspended solids (TSS) in sewage water are also high $(362 \mathrm{mg} / \mathrm{L})$ compared to tap water $(5.4$ $\mathrm{mg} / \mathrm{L}$ ), and is in correlation with the results of Krishnan et al. (2007) who got high TSS in sewage water reaching $150 \mathrm{mg} / \mathrm{L}$, and with results of AlSalem, (1987) who detected $900 \mathrm{mg} / \mathrm{L}$ TSS in wastewater in Amman, Jordan, also with the results of (Sulthana et al. 2013; Ghafoor et al. 1995). Carbonate $\left(\mathrm{HCO}_{3}\right)$ concentration in the sewage water is very high $(415 \mathrm{mg} / \mathrm{L})$ compared to tap water with only $(5.9 \mathrm{mg} / \mathrm{L})$. On the other hand, the phosphate (PO4), ammonium (NH4), nitrate (NO3), nitrite $\left(\mathrm{NO}_{2}\right)$, are high in sewage water compared to tap water. This is in agreement with the results of [Ghafoor et al. 1995] who advocated high values of $\mathrm{pH}$, hardness, alkalinity, total soluble salts, nitrates, nitrites, and cations like sodium, potassium, calcium, and magnesium in sewage water compared to normal water. As for the macro-elements $\mathrm{Ca}, \mathrm{Mg}$, $\mathrm{K}, \mathrm{Na}, \mathrm{Cl}$ their concentrations are significantly high in sewage water compared to normal water, and the highest concentration is for the chloride $(\mathrm{Cl})$ and sodium ( $\mathrm{Na}$ ). This is positively correlated with the findings of Krishnan et al. (2007) and Abdel-Ghaffar et al. (1988) who registered concentration of $\mathrm{Cl}$ in wastewater up to 222.1 and $320 \mathrm{mg} / \mathrm{L}$, and $\mathrm{Na}$ up to $205 \mathrm{mg} / \mathrm{L}$, Ca up to $128 \mathrm{mg} / \mathrm{L}, \mathrm{Mg}$ up to $96 \mathrm{mg} / \mathrm{L}, \mathrm{K}$ up to $35 \mathrm{mg} / \mathrm{L}$. Iron (Fe) is negligible in both sewage and tap water.

\section{Macro-elements in Sea and shore water}

in polluted and unpolluted sites:

The macro-elements calcium ( $\mathrm{Ca})$, magnesium $(\mathrm{Mg})$, potassium $(\mathrm{K})$, phosphorus $(\mathrm{P})$, sodium $(\mathrm{Na})$, 
chlorides $(\mathrm{Cl})$ analyzed in Sea and shore water gave variable concentrations in these waters, and all gave higher concentrations in polluted site compared to the unpolluted site, with significant differences in concentrations between the two sites in both Sea and shore water in the case of $\mathrm{Mg}, \mathrm{K}$ and $\mathrm{P}$. Chlorides (15722 mg/L and $19702 \mathrm{mg} / \mathrm{L}$ ) and sodium (11561 $\mathrm{mg} / \mathrm{L}$ and $13373 \mathrm{mg} / \mathrm{L}$ ) attained very high concentrations in both Sea and shore water in polluted and in unpolluted sites. This is positively correlated with the values obtained by (Anthoni, 2006) who found that chlorides ( $\mathrm{Cl}$ ) and sodium ( $\mathrm{Na}$ ) in seawater had attained the highest concentrations (19345 and $10752 \mathrm{mg} / \mathrm{L}$ respectively). This result can also be correlated with the results of (Rump,1999) who said that Sodium ( $\mathrm{Na}$ ) is one of the elements in natural waters and its concentration varies and reaches more than $1000 \mathrm{mg} / \mathrm{L}$ in salty waters and its content increases in sewage water. Ca reached (416 $\mathrm{mg} / \mathrm{L}$ ) and $\mathrm{Mg}$ is high reached (1295 $\mathrm{mg} / \mathrm{L}$ ), and as (Rump, 1999) said Mg is one of the elements found in abundance in the earth crust. The concentration of the elements is higher in the shore water compared to the Seawater. This is because the shore water is not subjected to mixing with other water like seawater.

\section{Macro-elements in Sea and shore soil}

in polluted and unpolluted sites:

Concentrations of the macro-elements (Ca), $(\mathrm{Mg}),(\mathrm{K}),(\mathrm{P}),(\mathrm{Na}),(\mathrm{Cl})$ in Sea and shore soil show significant differences between the polluted and unpolluted sites and also between Sea and shore soil concentrations. Chlorides and sodium attained very high concentrations in both Sea and shore soils in polluted and in unpolluted sites, $\mathrm{Cl}$ gave (22281 $\mathrm{mg} / \mathrm{L}$ in polluted and $19115 \mathrm{mg} / \mathrm{L}$ in unpolluted Sea soil, and $21001 \mathrm{mg} / \mathrm{L}$ in polluted and $18444 \mathrm{mg} / \mathrm{L}$ in unpolluted shore soil) and $\mathrm{Na}$ attained $(10208 \mathrm{mg} / \mathrm{L}$ in polluted and $7773 \mathrm{mg} / \mathrm{L}$ in unpolluted Sea soil, and $6117 \mathrm{mg} / \mathrm{L}$ in polluted and $537 \mathrm{mg} / \mathrm{L}$ in unpolluted shore soil). $\mathrm{Mg}, \mathrm{K}, \mathrm{Na}$, and $\mathrm{Cl}$ gave higher concentrations in Sea soil compared to the shore soil, while concentrations of $\mathrm{Ca}$ and $\mathrm{P}$ are significantly high in shore soil than in Sea soil.
Heavy metals and trace elements in Sea and shore water in polluted and unpolluted sites:

These are elements which normally present in relatively low concentrations, usually less than a few $\mathrm{mg} / \mathrm{l}$. Heavy metals are a special group of trace elements and the ten studied here included Zinc $(\mathrm{Zn})$, Copper $(\mathrm{Cu})$, manganese $(\mathrm{Mn})$, boron (B), Chromium ( $\mathrm{Cr}$ ), nickel (Ni), molybdenum $(\mathrm{Mo})$, aluminum ( $\mathrm{Al})$, cobalt ( $\mathrm{Co})$, iron ( $\mathrm{Fe})$. These are called heavy metals because, in their metallic form, their densities are greater than $4 \mathrm{~g} / \mathrm{cc}$. Concentrations of most of these trace and heavy metals in the Sea and shore water are low less than one $(\leq 0.1 \mathrm{mg} / \mathrm{L})$, with exception of $\mathrm{Mn}$ with $8.4 \mathrm{mg} / \mathrm{L}$ in Seawater and $6.27 \mathrm{mg} / \mathrm{L}$ inshore water, B with $5.34 \mathrm{mg} / \mathrm{L}$ in Seawater and $6.57 \mathrm{mg} / \mathrm{L}$ in shore water and Al with $1.9 \mathrm{mg} / \mathrm{L}$ in Seawater and $2.1 \mathrm{mg} / \mathrm{L}$ inshore water. Concentrations of $\mathrm{Cu}, \mathrm{Mn}, \mathrm{Cr}, \mathrm{Ni}, \mathrm{Al}$ in Sea and shore water at the polluted site are significantly higher than their concentration in an unpolluted site, while Zn, B, Mo, Co, and Fe showed no significant differences between their concentrations in Sea and shore water between the polluted and unpolluted sites. These results are in positive correlation with the results of (Alghobara et al. 2014) who found a significant increase $(p<0.05)$ of $\mathrm{Fe}, \mathrm{Mn}, \mathrm{Cu}, \mathrm{Zn}$, and $\mathrm{Pb}$ in an area subjected to sewage water compared to an area not subjected to sewage water.

Heavy metals and trace elements in Sea and shore soil in polluted and unpolluted sites:

Concentrations of most of the trace and heavy metals in the Sea and shore soil are low less than one $(\leq 0.1 \mathrm{mg} / \mathrm{L})$, with exception of $\mathrm{Mn}$ with 8.74 $\mathrm{mg} / \mathrm{L}$ in Sea soil and $3.21 \mathrm{mg} / \mathrm{L}$ in shore soil, B with $2.49 \mathrm{mg} / \mathrm{L}$ in Sea soil and $6.91 \mathrm{mg} / \mathrm{L}$ in shore soil and Co with $1.3 \mathrm{mg} / \mathrm{L}$ in Sea soil and $0.24 \mathrm{mg} / \mathrm{L}$ in shore soil. There are significant differences between concentrations of $\mathrm{Cu}, \mathrm{Mn}, \mathrm{B}, \mathrm{Ni}, \mathrm{Co}$ in Sea and shore soil at the polluted site and unpolluted site, while $\mathrm{Zn}, \mathrm{Cr}, \mathrm{Co}$, and Fe showed no significant differences between their concentrations in Sea and shore water between the polluted and unpolluted sites. Zinc, $\mathrm{Cr}$ and Fe concentrations are very low in both Sea and shore soil, and $\mathrm{C} U$ and $\mathrm{B}$ concentrations are 
high in shore soil, but $\mathrm{Mn}$ concentration is high in Sea soil. It can be noted that the trace and heavy metal concentrations in Sea and shore water are higher than their concentrations in the Sea and shore soil except for Co. Ali et al. (1996) mentioned that sewage water contains significant amounts of toxic metals such as arsenic, chromium, cadmium, copper, lead, nickel, zinc, cobalt, magnesium and iron compared to soil.

\section{CONCLUSION}

There is an overall increase in the total dissolved solids (TDS), total suspended solids (TSS), bicarbonates, sulfates, phosphates, ammonium, and nitrates in the untreated and semi-treated sewage water compared to tap water. Calcium (Ca), $\mathrm{Mg}, \mathrm{K}, \mathrm{Na}, \mathrm{Cl}$ concentrations are higher in untreated and semi-treated sewage water than in tap water, particularly chlorides, sulfates, TDS which gave very high concentrations in sewage water. Sewage water untreated and semi-treated dominated tap water in concentrations of trace and heavy metals $\mathrm{Zn}, \mathrm{Cu}$, $\mathrm{Mn}, \mathrm{B}, \mathrm{Cr}, \mathrm{Ni}, \mathrm{As}$, and $\mathrm{Ba}$. The EC in Sea and shore water and soil in the polluted site are significantly higher than in unpolluted site. The concentrations of $\mathrm{Mg}, \mathrm{K}$, and $\mathrm{P}$ in Sea and shore water and $\mathrm{Ca}, \mathrm{Mg}, \mathrm{K}$, $\mathrm{P}$, and $\mathrm{Na}$ in Sea and shore soil in the polluted site is significantly higher than in the unpolluted site. Sodium ( $\mathrm{Na}$ ) and $\mathrm{Cl}$ concentrations are very high in Sea and shore water and soil in both polluted and unpolluted sites. The concentrations of $\mathrm{Cu}, \mathrm{Mn}, \mathrm{Cr}$, $\mathrm{Ni}, \mathrm{Al}$ in Sea and shore water and Sea and $\mathrm{Cu}, \mathrm{Mn}, \mathrm{B}$, $\mathrm{Ni}, \mathrm{Co}$, shore soil are significantly higher in polluted sites than in unpolluted sites. The dangers of discharging sewage water into the Red Sea water will pollute the Seawater and Shore soil, and this will be having adverse and toxic effects on fishes and other organisms living in Seawater, and these toxic metals will find their way into the fishes and consequently into the human body feeding on these fishes. Also, forage plant species growing in the vicinity of these areas will accumulate toxic heavy metals and when animals graze on them they will reach the human bodies. Discharge of industrial wastewater in seawater generally can lead to the accumulation of heavy metals in the tissues of the organisms (Gochfeld, 2003; Yi et al 2008).

\section{REFERENCES}

Abdel-Ghaffar A.S., El-Attar H.A. and Elsokkary I.H. (1988) Egyptian experience in the treatment and use of sewage and sludge in agriculture. Ch. 17, Treatment and Use of Sewage Effluent for Irrigation, M.B. Pescod and A. Arar (eds). Butterworths, Sevenoaks, Kent.

Alghobar, M. A.; Ramachandra, A. ; Suresha, S. (2014). Effect of sewage water irrigation on soil properties and evaluation of the accumulation of elements in Grass crop in Mysore city, Karnataka, India. American Journal of Environmental Protection 2014; 3(5): 283-291.

Ali, K., Javid, M.A., Javid, M., (1996). Pollution and industrial waste. 6th National Congress Soil Sci., Lahore. 122-131.

Al-Salem, (1987). Evaluation of Al- Samra Waste Stabilization Pond System and its suitability in unrestricted irrigation. Paper presented to the Land and Water Department Division . Food and Agriculture Organization , UN, Rome.

Anthoni, J.F.(2006). Chemical composition of seawater.

www.seafriends.org.nz/oceano/seawater.htm

Basaham, A. S., A. E., Rifaat, M. H., El-Mamoney and M. A., El-Sayed. (2009). Re-evaluation of the impact of sewage disposal on coastal sediments of the southern corniche, Jeddah, Saudi Arabia. J.K.A.U. Marine Sci., 20, 2009, pp.109-126.

Censi P.; Spoto SE.; Salano F.; Mazzola S. (2006). Heavy metals in coastal water system. A case study from the North Western Gulf of Thailand. Chemosphere 64:1167-1176.

Coban B.; Balkis N. and Aksu A. (2009). Heavy metal levels in Zonguldak, Turkey. J. Black Sea, Mediterranean Environ., vol.15: 23-32.

El Sayed, M.A. (2002b) Distribution and behavior of the dissolved species of nitrogen and phosphorus in two coastal Red Sea lagoons receiving domestic sewage, JKAU: Mar. Sci., 12: 47-73.

El-Khateeb, M.A. A.M. Arafa, A.M. Abd El-Dayem and R.A. Watfa (2012). Effect of Sewage Water 
Irrigation on Macro Nutrients, Heavy Metals and Frequency Percentage of Fungi in Soil Cultivated with Woody . Journal of Horticultural Science \& Ornamental Plants 4 (2): 177-185, 2012 ISSN 20792158

El-Nakhlawy F.S., Shaheen M. and Ishan M. (2016). Assessment of landscape health status by Cyperus rotundus and soil analysis under waste water irrigation. Planta Daninha 2017; v35:e017161097.

El-Riyadh News Paper (2012). Project signed to increase water supply in Kingdom. The Saudi National Water Company.

El-Sayed, M.A. and Niaz, G.R. (1999) Study of Sewage Pollution Profile along the Southern Coast of Jeddah, Study of Some Organic and Inorganic Pollutants. Report, KAU, SRC, p. 111.

El-Yami M.Y. (2010). Ecological studies of some Molluscs in Jeddah area on Red Sea Coast with special emphasis on the accumulation of certain heavy metals in their tissues. Ph.D thesis Zoology (Marine Science), 2010.

FAO. (1985). Water quality for agriculture. R.S. Ayers and D.W. Westcot. Irrigation and Drainage Paper 29 Rev. 1. FAO, Rome.174p.

Ghafoor, A., Rauf, A., Arif, M., Muzaffar, W., (1995). Chemical composition of effluent from different industries of the .Faisalabad city. Pak. J. Agric. Sci., 31: (4) 367-369.

Gupta, S., S. Nayek, R.N. Saha and S. Satpati, 2008. Assessment of heavy metal accumulation in macrophyte, agricultural soil and crop plants adjacent to discharge zone of sponge iron factory. Environ. Geol., 55: 731-739.

Krishnan, R. R.; Dharmaraj, K.; Kumari, B. D. (2007). A comparative study on the physicochemical and bacterial analysis of drinking, borewell and sewage water in the three different places of Sivakasi. Journal of Environmental Biology January, 28(1) 105-108

Pote JL, Haller JL, Loizeau AG, Bravo V, Satri G; Wildi W. (2008). Effect of sewage treatment plant outlet pipe extension on the distribution of contaminants in the sediment of the bay of Vidy, lake Geneva, Swizerland, Bioresour, Twchnol; 99:7122-7131.

Radwan K.M. (2009). Spacial and seasonal distribution of total dissolved copper and nickel in the surface coastal waters of Rabigh, Eastern Red Sea, Saudi Arabia. J. Earth Sci., vol. 22, No. 1: pp. 29-44.

Rump,H.H., (1999). Laboratory Manual for the examination of water, wastewater and soil. 3rdedn., Wily-VHC. New York.

Saad MAH and Fahmy MA (2009) Heavy metal pollution in coastal Red

Sea waters, Jeddah. J KAU: Mar Sci 7:67-73

Sulthana, A., Latha, K.C., Ramya, R., Sridhar, R., Balasubramanian, S., (2013). Factor Analysis and Discriminant Analysis of Wastewater Quality in Vidyaranyapuram Sewage Treatment Plant, Mysore, India: A Case Study. Environmental \& Analytical Toxicology. 3-7.

Wcisio E; Loven D; Kucharski R; Szdzuj J (2008). Human health risk assessment, case study. An abandoned metal smelter site in Poland. Chemosphere 96:223-230.

Wen C; Kao CF; Chen CF; Dong CD (2007). Distribution and accumulation of heavy metals in sediments of Cachsiung harbor. Taiwan. Chemosphere 66:1431-1440. 